\title{
New paleomagnetic pole for the Upper Jurassic Chon Aike Formation of southern Argentina (South America): Testing the tectonic stability of Patagonia with respect to South America, and implications to Middle Jurassic-Early Cretaceous true polar wander
}

\author{
Víctor Ruiz González ${ }^{\mathrm{a}, *}$, Carla G. Puigdomenech ${ }^{\mathrm{a}}$, Emiliano M. Renda ${ }^{\mathrm{a}}$, Bárbara Boltshauser ${ }^{\mathrm{a}}$, \\ Rubén Somoza $^{\mathrm{a}}$, Haroldo Vizán ${ }^{\mathrm{a}}$, Claudia B. Zaffarana ${ }^{\mathrm{b}}$, Graeme K. Taylor ${ }^{\mathrm{c}}$, Miguel Haller ${ }^{\mathrm{d}}$, \\ Raúl Fernández
}

${ }^{a}$ IGEBA, UBA - CONICET, Argentina

${ }^{\mathrm{b}}$ IIPG, UNRN - CONICET, Argentina

${ }^{\mathrm{c}}$ Plymouth University, United Kingdom

${ }^{\mathrm{d}}$ CENPAT, CONICET - UNPSJB, Argentina

e INREMI, UNLP, Argentina

\section{A R T I C L E I N F O}

\section{Keywords:}

Chon Aike Formation

Deseado Massif

South America

Paleomagnetism

Apparent polar wander path

\begin{abstract}
A B S T R A C T
A paleomagnetic pole and a new Ar-Ar date of $156.08 \pm 0.05 \mathrm{Ma}$ are reported for the Chon Aike Formation, an extensive plateau of ignimbrites, outcropping in the Deseado Massif (southern Patagonia, Argentina). The geographic coordinates and statistical parameters for the paleomagnetic pole, validated by a reversal test, are: Lat. $=84.3^{\circ} \mathrm{S}$, Long. $=191.3^{\circ} \mathrm{E}, \mathrm{A}_{95}=8.6^{\circ}, \mathrm{K}=13.3, \mathrm{~N}=23$. This pole shows a complete coherence with Late Jurassic and Early to mid-Cretaceous poles of South America, obtained exclusively from igneous rocks, avoiding any potential inclination shallowing. It is suggested that; a) southern Patagonia was an integral part of South America in the Late Jurassic; b) any reported vertical axis tectonic rotations must pre-date the Late Jurassic in this region; c) according to updated paleomagnetic data from igneous rocks, South America had very limited latitudinal drift between about 160 and $140 \mathrm{Ma}$; and, therefore, d) its apparent polar wander (APW) path, when compared with global apparent polar wander paths, does not support a large global shift or true polar wander (TPW) between 160 and $140 \mathrm{Ma}$.
\end{abstract}

\section{Introduction}

Paleomagnetism is an important tool for paleogeographic reconstructions and geodynamic analysis. This can be achieved by comparison of apparent polar wander (APW) paths which are a temporal sequence of paleomagnetic poles, obtained from a variety of rock types. APW paths record the tectonic movements of lithospheric plates and, if active, true polar wander (TPW) which is the displacement of an entire, rigid Earth with respect to its spin axis (Goldreich and Toomre, 1969; Gordon and Livermore, 1987). Paleomagnetic poles are also very useful to test tectonic rotations (around a vertical axis) of lithospheric blocks due to the activity of fault systems with lateral displacements.

Using an APW track of paleomagnetic poles, Kent et al. (2015) have suggested that a TPW episode took place between about 160 and
$140 \mathrm{Ma}$, which should be testable by reliable paleomagnetic poles from well-dated units of different plates around the globe.

The aim of the present work is to constrain the timing of block tectonic rotations in the Deseado Massif of southern Patagonia and to test if paleomagnetic data from South America supports the proposal of a large shift of the whole rigid Earth during the Late Jurassic. To fulfill these goals, paleomagnetic sampling was carried out in the Chon Aike Formation. Its outcrops in the Deseado Massif (Santa Cruz Province Argentina) are considered an integral part of South American Plate during Jurassic times (von Gosen and Loske, 2004; Zaffarana et al., 2010).

A reliable paleomagnetic pole was obtained from several volcanic flows for which geographic coordinates and statistical parameters are: Lat. $=84.3^{\circ} \mathrm{S}$, Long. $=191.3^{\circ} \mathrm{E}, \mathrm{A}_{95}=8.6^{\circ}, \mathrm{K}=13.3, \mathrm{~N}=23$. The

\footnotetext{
* Corresponding author at: Instituto de Geociencias Básicas, Aplicadas y Ambientales de Buenos Aires, UBA - CONICET, Oficina 27 - Departamento de Ciencias Geológicas, Facultad de Ciencias Exactas y Naturales - UBA, Intendente Güiraldes 2160, CABA, Argentina.

E-mail address: vruizgonzalez@gl.fcen.uba.ar (V. Ruiz González).
} 
Table 1

Site: number of paleomagnetic sampling sites; Lat. And Long.: geographic coordinates of these sites; N/n: number of collected samples vs. Number of directions used for the site means; Dec. And Inc.: declination and inclination of the site mean directions; $\alpha_{95}$ : $95 \%$ cone of confidence of site mean directions; k: kappa, precision poaramenter of Fisher (1953); Pole Lat. And Pole Long.: geographic coordinates of virtual geomagnetic poles (VGPs). * Discarded because of its large confidence cone $\left(\alpha_{95}=37.4^{\circ}\right)$, the site also could correspond to an edge of a volcano caldera. ** Sites with VGPs away from the cutt of angle determined using Wilson et al. (1972) method applied iteratively. Calculated mean directions for 30 and 23 sites used to calculate the reversal test (see text).

\begin{tabular}{|c|c|c|c|c|c|c|c|c|c|c|c|c|c|}
\hline \multirow[t]{2}{*}{ Site } & \multirow[t]{2}{*}{ Lat. $\left({ }^{\circ} \mathrm{S}\right)$} & \multirow[t]{2}{*}{ Long. $\left({ }^{\circ} \mathrm{E}\right)$} & \multirow[t]{2}{*}{$\mathrm{N} / \mathrm{n}$} & \multicolumn{2}{|c|}{ In situ } & \multicolumn{2}{|c|}{ Bedding correction } & \multicolumn{2}{|c|}{ Tilt corrected } & \multirow[t]{2}{*}{$\alpha 95$} & \multirow[t]{2}{*}{$\mathrm{k}$} & \multicolumn{2}{|l|}{ VGPs } \\
\hline & & & & Dec. & Inc. & Strike & Dip & Dec. & Inc. & & & Pole Lat. & Pole Long. \\
\hline 1 & 47.5800 & -69.7710 & $8 / 7$ & 201.4 & 70.8 & Horizontal & & 201.4 & 70.8 & 3.1 & 373.4 & -74.7 & 237.6 \\
\hline 2 & 47.6122 & -69.7689 & $6 / 6$ & 173.1 & 67.3 & Horizontal & & 173.1 & 67.3 & 5.6 & 146.6 & -84.8 & 359.5 \\
\hline 3 & 47.6315 & -69.7555 & $5 / 5$ & 168.2 & 76.4 & Horizontal & & 168.2 & 76.4 & 3.4 & 516.7 & -72.3 & 307.3 \\
\hline 4 & 47.7587 & -69.7041 & $5 / 5$ & 167.9 & 58.8 & Horizontal & & 167.9 & 58.8 & 7.2 & 112.9 & -78.0 & 59.0 \\
\hline 5 & 47.8100 & -69.7008 & $11 / 9$ & 162.1 & 65.5 & Horizontal & & 162.1 & 65.5 & 4.2 & 153.7 & -78.0 & 14.4 \\
\hline $6^{* *}$ & 47.7653 & -69.7008 & $7 / 7$ & 322.2 & 85.6 & 200 & 10 & 299.8 & 76.1 & 6.6 & 85.0 & -31.0 & 263.6 \\
\hline 7 & 47.8145 & -69.9409 & $6 / 6$ & 9.4 & -50.0 & Horizontal & & 9.4 & -50.0 & 4.2 & 259.5 & 71.5 & 316.3 \\
\hline 8 & 47.8193 & -69.9309 & $7 / 7$ & 163.1 & 52.6 & Horizontal & & 163.1 & 52.6 & 4.2 & 207.7 & -70.7 & 62.9 \\
\hline 9 & 47.9117 & -70.0208 & $5 / 5$ & 217.5 & 43.9 & Horizontal & & 217.5 & 43.9 & 11.9 & 42.6 & -53.3 & 176.3 \\
\hline 10 & 47.9228 & -69.8090 & $7 / 6$ & 322.0 & -48.4 & Horizontal & & 322.0 & -48.4 & 9.8 & 47.7 & 55.5 & 218.7 \\
\hline $11^{* *}$ & 47.9266 & -69.6652 & $5 / 4$ & 288.6 & -64.7 & Horizontal & & 288.6 & -64.7 & 6.8 & 184.9 & 43.4 & 173.8 \\
\hline 12 & 47.9166 & -69.6736 & $6 / 3$ & 177.2 & 48.6 & Horizontal & & 177.2 & 48.6 & 13.2 & 88.0 & -71.5 & 102.7 \\
\hline 13 & 47.9259 & -69.5375 & $4 / 4$ & 192.0 & 70.9 & Horizontal & & 192.0 & 70.9 & 6.0 & 235.4 & -79.5 & 249.7 \\
\hline $14 * *$ & 47.9249 & -69.5410 & $6 / 6$ & 89.4 & 18.8 & Horizontal & & 89.4 & 18.8 & 6.1 & 120.2 & -6.8 & 13.5 \\
\hline $15^{* * *}$ & 47.9336 & -69.3577 & $5 / 5$ & 157.3 & 26.7 & Horizontal & & 157.3 & 26.7 & 2.6 & 854.5 & -51.3 & 73.9 \\
\hline 16 & 47.9297 & -69.3687 & $5 / 5$ & 240.7 & 71.2 & Horizontal & & 240.7 & 71.2 & 2.7 & 804.8 & -52.9 & 236.2 \\
\hline 17 & 46.9686 & -70.5638 & $7 / 6$ & 187.6 & 65.0 & Horizontal & & 187.6 & 65.0 & 5.5 & 151.0 & -84.8 & 202.4 \\
\hline 18 & 47.0178 & -70.5098 & $7 / 7$ & 342.0 & -72.4 & Horizontal & & 342.0 & -72.4 & 3.2 & 365.5 & 74.9 & 148.8 \\
\hline 19 & 46.9023 & -70.4732 & $9 / 7$ & 23.1 & -75.9 & Horizontal & & 23.1 & -75.9 & 11.2 & 29.9 & 69.1 & 80.0 \\
\hline 20 ** & 47.0215 & -70.5414 & $7 / 7$ & 108.2 & 46.6 & Horizontal & & 108.2 & 46.6 & 6.9 & 82.7 & -32.0 & 11.6 \\
\hline 21 & 46.9457 & -70.4842 & $11 / 11$ & 171.4 & 60.2 & Horizontal & & 171.4 & 60.2 & 4.0 & 131.0 & -81.5 & 60.0 \\
\hline 22 & 47.2290 & -70.7265 & $8 / 4$ & 9.9 & -65.0 & Horizontal & & 9.9 & -65.0 & 18.3 & 26.1 & 83.3 & 21.2 \\
\hline 23 & 47.2363 & -70.5457 & $8 / 8$ & 334.8 & -69.7 & 180 & 10 & 3.1 & -71.6 & 4.2 & 175.2 & 80.6 & 98.8 \\
\hline $24 * *$ & 47.4326 & -69.5457 & $9 / 7$ & 81.6 & 59.4 & Horizontal & & 81.6 & 59.4 & 10.7 & 33.0 & -23.6 & 345.0 \\
\hline 25 & 47.3211 & -68.5457 & $7 / 7$ & 207.2 & 52.6 & Horizontal & & 207.2 & 52.6 & 4.6 & 170.6 & -65.0 & 174.7 \\
\hline 26 & 47.3048 & -67.5457 & $6 / 6$ & 200.7 & 27.7 & Horizontal & & 200.7 & 27.7 & 4.5 & 223.1 & -53.1 & 144.2 \\
\hline $27^{* *}$ & 47.0091 & -66.5457 & $5 / 5$ & 282.6 & 74.2 & 220 & 5 & 288.9 & 69.7 & 5.1 & 223.7 & -27.1 & 250.8 \\
\hline 28 & 47.0693 & -65.5457 & $5 / 4$ & 32.2 & -40.7 & Horizontal & & 32.2 & -40.7 & 5.7 & 265.0 & 54.9 & 348.6 \\
\hline 29 & 47.1902 & -64.5457 & $5 / 3$ & 232.2 & 79.9 & 200 & 5 & 250.3 & 76.5 & 11.2 & 122.4 & -49.5 & 251.3 \\
\hline $30 *$ & 47.3898 & -63.5457 & $5 / 3$ & 136.0 & -27.3 & 225 & 65 & 136.1 & 37.7 & 37.4 & 11.9 & -58.3 & 40.3 \\
\hline 31 & 47.0897 & -62.5457 & $5 / 3$ & 16.3 & -60.6 & Horizontal & & 16.3 & -60.6 & 21.1 & 35.1 & 77.1 & 0.6 \\
\hline \multicolumn{4}{|c|}{ Mean directions (paleohorizontal) } & & $\mathrm{N}$ & \multicolumn{2}{|c|}{ Dec. } & \multicolumn{2}{|l|}{ Inc. } & \multicolumn{2}{|l|}{$\mathrm{R}$} & $\mathrm{k}$ & $\alpha 95$ \\
\hline \multirow[t]{2}{*}{23 sites } & & \multicolumn{2}{|c|}{ Reverse } & & 15.0 & \multicolumn{2}{|c|}{190.2} & \multicolumn{2}{|l|}{62.7} & \multicolumn{2}{|l|}{14.3} & 21.0 & 8.5 \\
\hline & & \multicolumn{2}{|c|}{ Normal } & & 8.0 & \multicolumn{2}{|c|}{5.4} & \multicolumn{2}{|l|}{-62.6} & 7.7 & & 21.5 & 12.2 \\
\hline
\end{tabular}

Chon Aike Formation's paleomagnetic sites belong to a voluminous unit of ignimbrites, in which fiammes indicate that it was deposited horizontal to sub-horizontally and an absence of subsequent deformation. Only one sampling site (number 30 in Table 1) belongs to a bed with a dip of $65^{\circ}$ that was later discarded given the level of uncertainty of its paleomagnetic direction (see below). The northern part of the formation has been well-constrained age-wise (Pankhurst et al., 2000; Féraud et al., 1999), however, its outcrops cover a large area and there is only one available age in its central area and two in the southern part (see Fig. 1).

The new pole for the Chon Aike Formation, presented in this work, precisely constrains the age of tectonic rotations to the Late Jurassic, possibly before the breakup of Western Gondwana (see Somoza et al., 2008). Moreover, when it is compared with previously reported paleomagnetic poles from Early Jurassic to mid-Cretaceous igneous units of South America, it precludes any appreciable latitudinal drift of this continent during the Late Jurassic.

\section{Geological setting and paleomagnetic sampling}

During Jurassic times, voluminous volcanism developed over a wide area of Patagonia, which was named by Kay et al. (1989) as the Chon Aike Magmatic Province. The distribution of this magmatic province includes the North Patagonian and Deseado Massifs (Río Negro, Chubut and Santa Cruz Argentinian provinces), as well as parts of Tierra del Fuego, Antarctica and the South Atlantic Islands Province (Pankhurst et al., 2000). In the extra Andean area of the Deseado Massif, there is an important sequence of volcanogenic rocks that forms part of this magmatic province, including the pyro- and epiclastitic lithologies of the Roca Blanca Formation, lavas and subvolcanic bodies of the Bajo Pobre Formation, and the pyro-epiclastitic rocks and lavas of Bahía Laura Group, which includes the Chon Aike Formation (Panza and Haller, 2002).

Paleomagnetic sampling was carried out in an ignimbritic plateau of about $18,000 \mathrm{~km}^{2}$, in the western part of the Chon Aike Formation (Fig. 1). This plateau constitutes a sequence of ca. 1,300 $\mathrm{m}$ of fallout tuffs and ignimbrites that correspond to several cycles of eruptive activity (Echeveste et al., 1999). The thickness of each ignimbrite flow varies between 5 and $15 \mathrm{~m}$ (Fig. 2), and, in extreme cases, up to $35 \mathrm{~m}$. Its dominant color in outcrop is dark brown to reddish, sometimes light and dark gray, while in fresh faces they can show a pinkish to reddish gray and purple coloration. The ignimbrites contain abundant fiammes with diameters ranging between 2 and ca. $10 \mathrm{~cm}$. Some of these fiammes have been replaced by calcite-filled cavities. It is important to note that both the fiammes and the cavities are parallel to subparallel to the ignimbrite beds, which are horizontal to sub-horizontal. This bedding plane is also shown in many cases by biotite sheets within the ignimbrites (Fig. 3). 

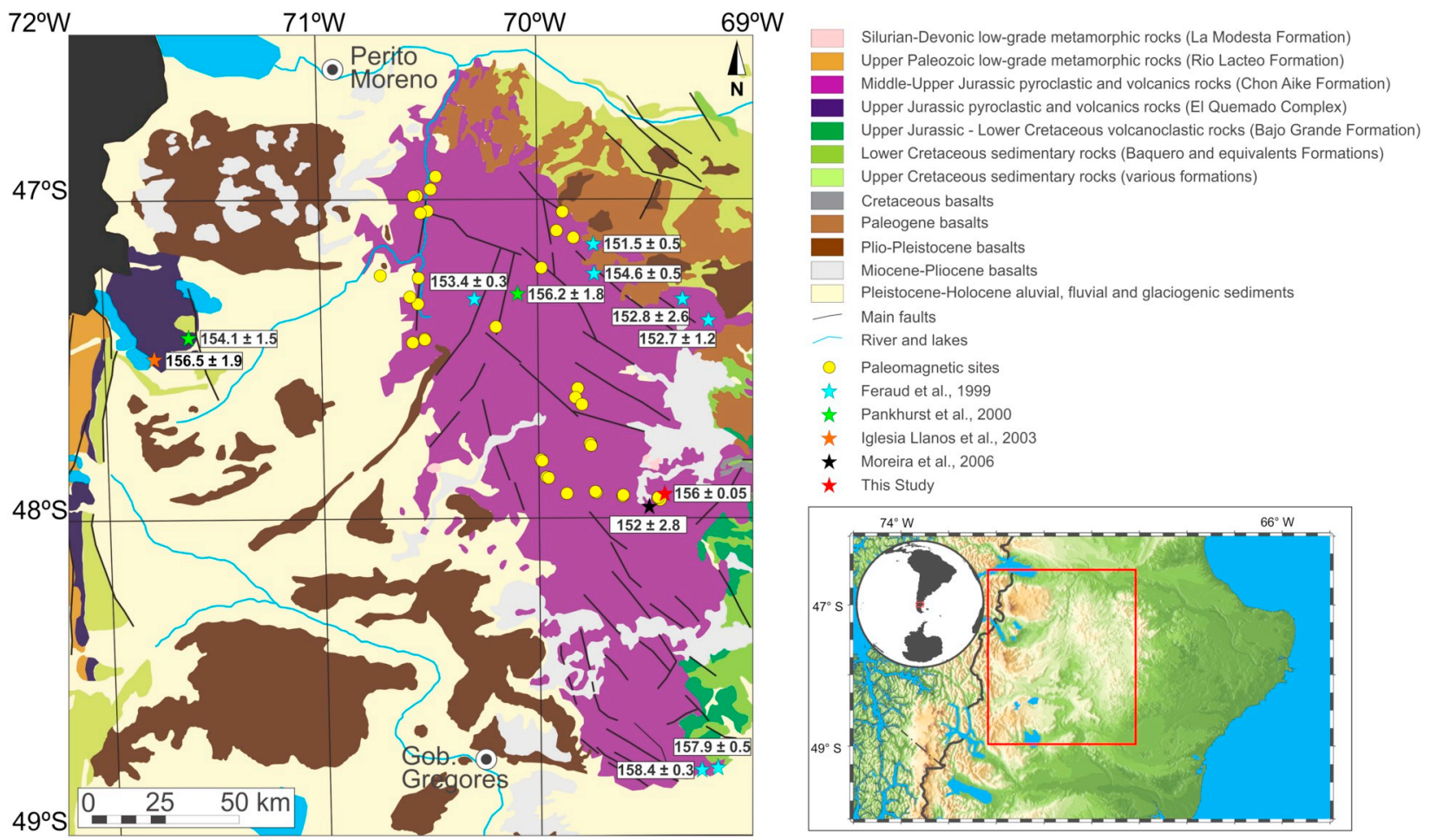

Fig. 1. Geologic map of the sampled ignimbritic plateau and its location map. Dated localities are marked with stars and paleomagnetic sampling sites with yellow circles. (For interpretation of the references to color in this figure legend, the reader is referred to the web version of this article.)

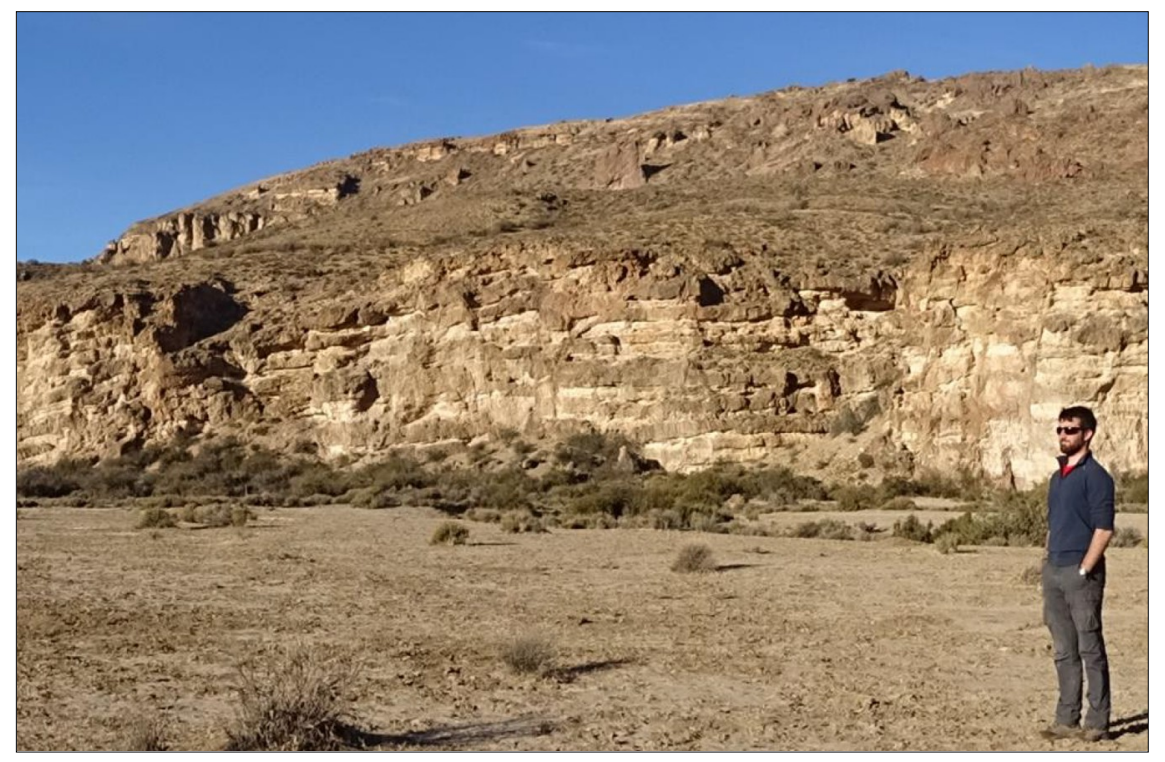

Fig. 2. Picture of one of the sequences of ignimbrites in the Río Pinturas creek. Note the thickness of each ignimbrite and the original horizontality.

Paleomagnetic sampling was carried out in the northern and central areas of the plateau (see Fig. 1). In order to average out paleosecular variation of the Earth magnetic field (EMF), 31 paleomagnetic sites were sampled from different ignimbrite flows. These samples were collected using a portable core-drilling machine and oriented using magnetic and solar compasses. Five to eleven samples were taken from each site (Table 1). The sampling was carried out extending over several meters laterally along each ignimbrite flow, and high ground was avoided in order to reduce the possibility of remagnetization of the flows due to lightning strikes.

\section{Petrographic description}

Petrographic analyses were carried out to characterize their primary mineralogical composition and to determine any post-depositional alteration that could have affected the original magnetic carriers. The ignimbrites are composed mainly of crystalloclasts of quartz, plagioclase and biotite or amphibole. Euhedral to subhedral zircons and apatites were detected as minor components. Most of the quartz crystals show embayments of corrosion. Plagioclases are zoned (rarely altered to sericite), and biotites show different degrees of alteration to opaque 


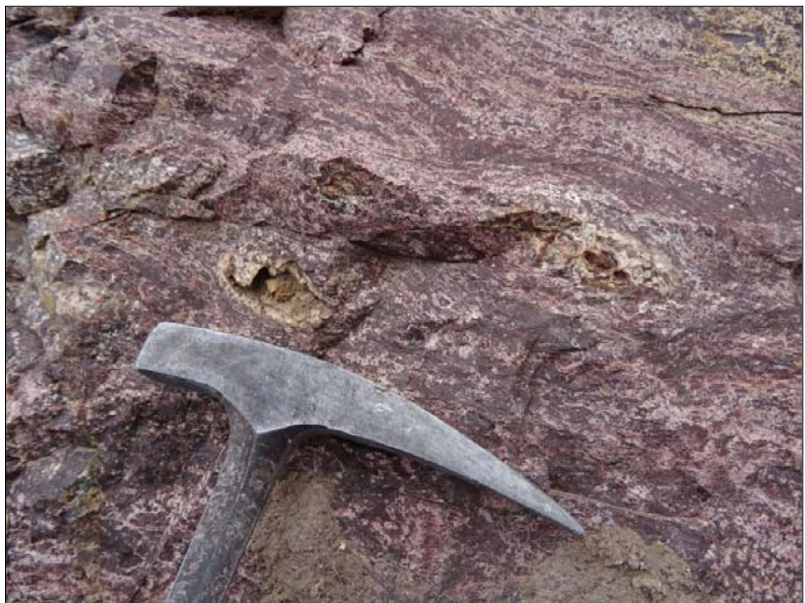

Fig. 3. Flux of ignimbrite parallel to bedding planes marked by fiammes and the fluidal distribution of the minerals.

minerals. The matrix of the ignimbrites is recrystallized, including glass shards and showing different degrees of welding. In all cases, opaque minerals are present, and sometimes rutile appears as an accessory. The fiammes are devitrified and show strong orientation with evidence of flux (Fig. 4a). Reflected light analysis shows magnetite altered to hematite that could be the potential magnetic carrier (Fig. 4b).

\section{Radiometric dating}

A paleomagnetic pole named Chon Aike (CA) has been listed in various databases (e.g., Torsvik et al., 2012; Kent and Irving, 2010) and has been assigned an age of 165-170 Ma. However, the units sampled for that paleomagnetic pole belongs to the broad "Chon Aike Magmatic Province", which is composed of several different formations with ages ranging between $158.4 \mathrm{Ma}$ (Féraud et al., 1999) and $178.4 \mathrm{Ma}$ (Pankhurst et al., 2000). This huge magmatic province is located farther east where it is extremely difficult to determine sequences with several stratigraphic levels of ignimbrites (Somoza et al., 2008). Hence, we are unclear as to whether the previous pole contains enough individual flows to adequately average out secular variation.

The Chon Aike Formation, which constitutes the ignimbritic plateau studied here, has been investigated age-wise by various authors using different dating techniques. In this plateau, there are 6 similar radiometric age determinations with a mean value of $\sim 154 \mathrm{Ma}$ in the northern part (see Fig. 1) and 2 radiometric ages in the southern part with an average age of $158 \mathrm{Ma}$. For the rocks sampled in the central area, there is only one published age of $152 \pm 2.8 \mathrm{Ma}$ by U-Pb SHRIMP in zircons, obtained on a brownish strongly welded ignimbrite (Moreira et al., 2006).

In this paper, we collected a grayish ignimbrite at $47.96^{\circ} \mathrm{S}, 69.37^{\circ} \mathrm{W}$, which underlies and therefore pre-dates the $152 \mathrm{Ma}$ flow. This sample was dated by the $\mathrm{Ar}^{39} / \mathrm{Ar}^{40}$ method in individual biotite crystals (Fig. 5a) and its weighted mean age (from 19 crystals) is $156.08 \pm 0.05(2 \sigma)$, and therefore similar to the age of the overlying ignimbrite. The sample gave a plateau age of $156.15 \pm 0.38$ for the ${ }^{39} \mathrm{Ar}$ released. There is no statistical difference between the plateau age and the inverse isochron age (156.82 \pm 0.77$)$, and the initial ratio is smaller than atmospheric, demonstrating that the age has not been influenced by excess argon (Fig. 5b). The study of this sample was undertaken by the OSU Argon Geochronology Lab, CEOAS Oregon State University, Corvallis. The new radiometric age underpins the age of our paleomagnetic sampling sites in the central part of the plateau.

This result confirms that all the ages obtained in the different localities of the ignimbritic plateau range between 151.5 and $158.4 \mathrm{Ma}$, so the age of our reported paleomagnetic data represents a portion of this time interval. We consider it appropriate to assign an average age of $155.0 \pm 3.5 \mathrm{Ma}$ to the Chon Aike Formation paleomagnetic pole (where the error bar corresponds to the range of all reported ages, Fig. 1).

\section{Paleomagnetic results}

The oriented paleomagnetic samples were processed in the Laboratory of Paleomagnetism "Daniel A. Valencio" in the Department of Geological Sciences of the University of Buenos Aires (Argentina). The samples were sliced into one or two specimens of fresh rock, of $2.5 \mathrm{~cm}$ in diameter and $2.2 \mathrm{~cm}$ length. Natural remanent magnetization

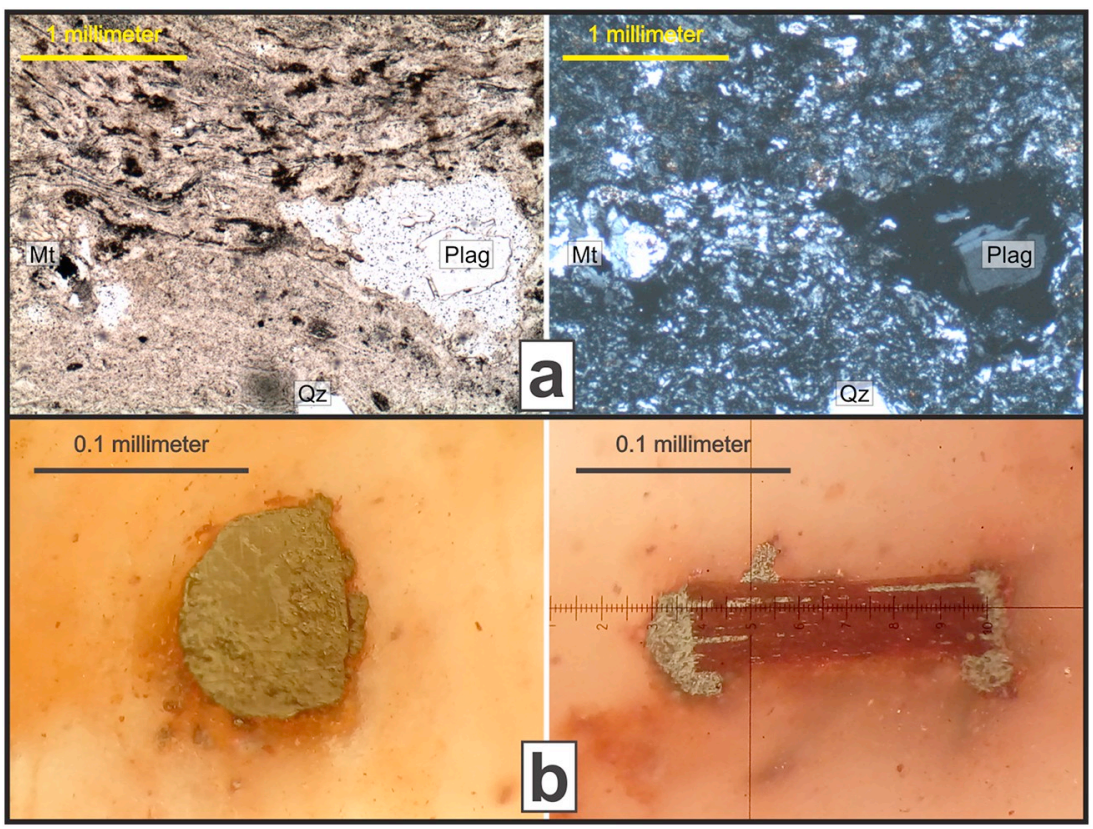

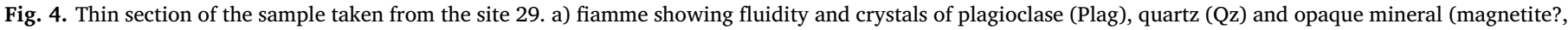
$\mathrm{Mt}$ ) in a devitrified matrix; b) crystals of magnetite altered to hematites (left) and rutile with hematite (right). 

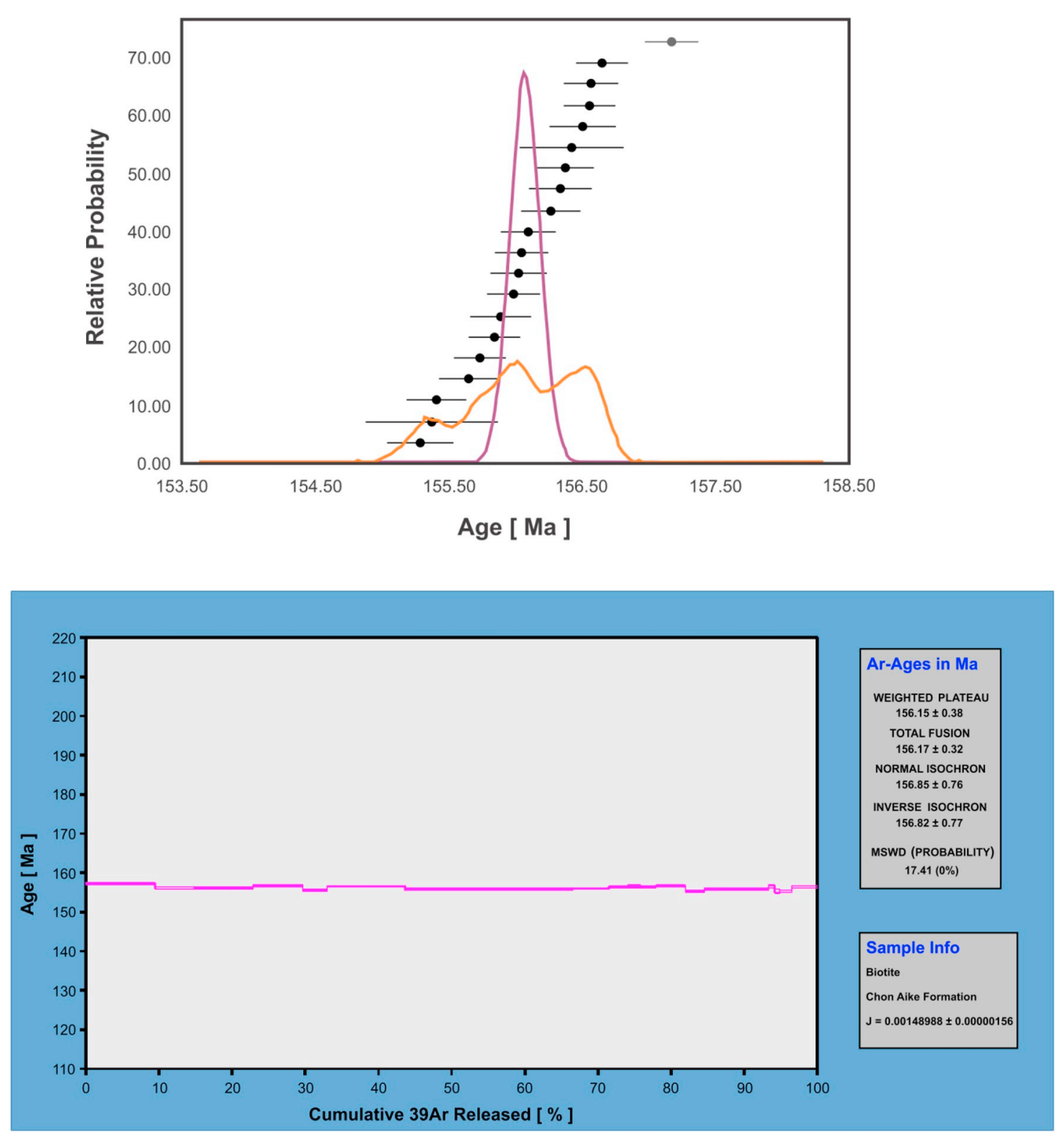

Fig. 5. Results of the Ar-Ar method in biotite crystals showing the mean age for the site.

(NRM) before and after demagnetization were determined using an AGICO JR6 magnetometer and a $2 \mathrm{G}$ cryogenic magnetometer which includes a three-axis AF demagnetizer. The stability of the NRM was tested by progressive thermal or alternating field (AF) demagnetization. Thermal demagnetization was performed using an ASC scientific oven. Bulk susceptibility measurements were carried out with an MS2 Bartington instrument after each heating step to monitor the occurrence of chemical possible changes induced by heating. Anisotropy of magnetic susceptibility (AMS) and thermomagnetic curves were determined with a multifunction Kappabridge MFK1. The ChRM of each specimen was determined by applying a least squares line fit (Kirschvink, 1980).

AF demagnetization defined a component of high coercivity after $10 \mathrm{mT}$ (Fig. 6a). These samples have thermomagnetic curves with Curie temperatures similar to those of (titano-)magnetites (Fig. 6b). It is observed that the spectrum appears to be modified with heating, reaching lower Curie temperatures on cooling, which may be due to the exsolution of members of the solid solution series. An irreversible drop in susceptibility around $300-400{ }^{\circ} \mathrm{C}$ may indicate maghemitization of the sampled rocks (in agreement with reflected light analysis). In few cases, the use of AF was not effective in completely demagnetizing the samples (Fig. 6c) and IRM studies of these samples show, the presence of a high coercivity phase along with (titano)magnetites (Fig. 6d). The IRM acquisition curves of these types of samples shows a sharp rise of magnetization in magnetic fields $(\mathrm{H})$ at $<200 \mathrm{mT}$, followed by a more gradual acquisition of additional IRM in stronger $\mathrm{H}$. The application of a backfield shows a minimum remanent coercive force (Hcr) around $110 \mathrm{mT}$. For these cases, the thermal demagnetization method was used exclusively to identify remanent components (Fig. 6e). For the majority of samples, in specimens of the same sample, both AF and thermal demagnetizations yielded similar ChRM components (Fig. 6f). In consequence, it was possible to define a component of high coercivity and high unblocking temperature, showing positive and negative inclinations (dual polarity, see Fig. 6a and e). Characteristic remanent magnetizations (ChRM) where determined with maximum angle deviations $(\mathrm{MAD}) \leq 10^{\circ}$.

Site mean directions were found from between three to eleven ChRMs (Fisher, 1953; see Table 1). 30 site mean directions were accepted for the rest of the analysis, following the criteria of Lanza and 


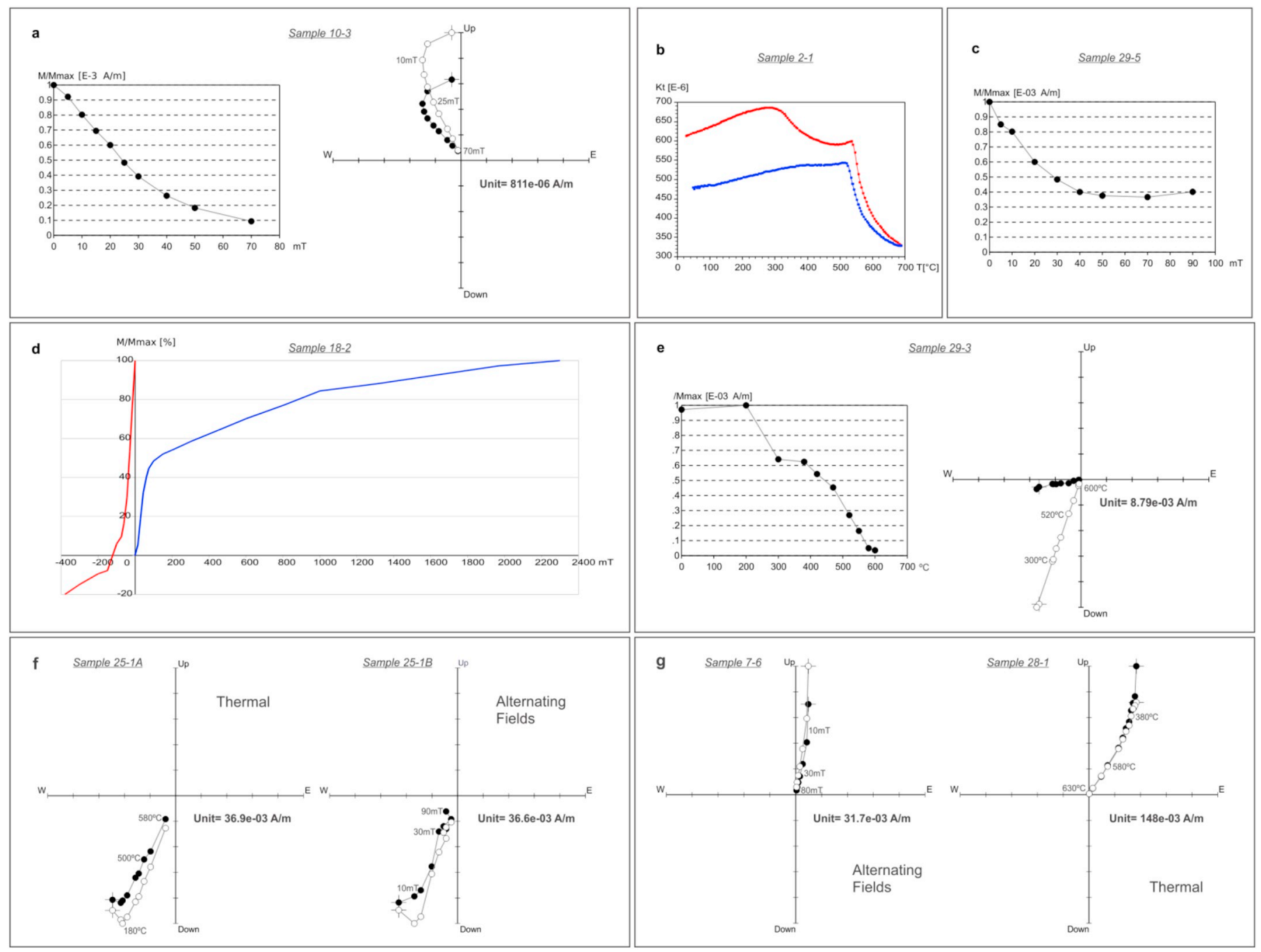

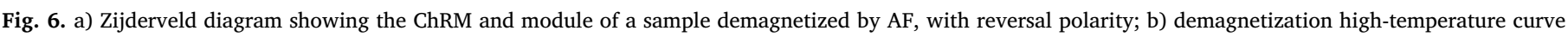

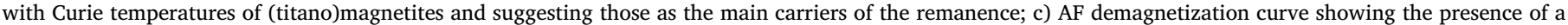

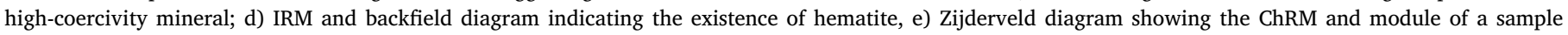

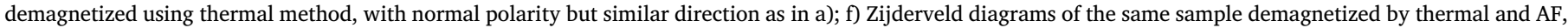

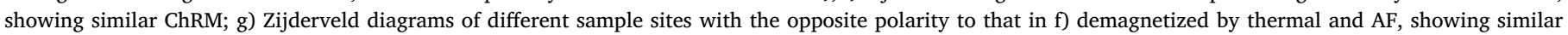
ChRM.

Meloni (2006), while one site (30; Table 1) mean direction was discarded because of its large confidence cone $\left(\alpha_{95}=37.4\right)$. Incidentally, the discarded site is the only one that has a bedding dip of $65^{\circ}$ and could correspond to an edge of a volcano caldera. In the other 21 (9) sites positive (negative) inclinations were observed, implying a dual polarity record. These data, however, show a high degree of between-site scatter in their mean directions (Fig. 7a) and so anisotropy of magnetic susceptibility (AMS) studies were performed to test if the flow-induced ignimbrite fabric had deflected the ChRM's. Sites 14 and 22, which show markedly different ChRM's (see Table 1), display consistent flat lying fabrics (Fig. 8). The mean tensors of site $14(\mathrm{~N}=7)$ are $\mathrm{K}_{1}=1.008, \mathrm{~K}_{2}=1.005, \mathrm{~K}_{3}=0.987$; and those of site $22(\mathrm{~N}=9)$ are: $\mathrm{K}_{1}=1.007, \mathrm{~K}_{2}=1.004, \mathrm{~K}_{3}=0.989$. Together, these data suggest that the CHRMs are not affected by the anisotropy, but the scatter in directions is a true record of the Earth's Magnetic Field. This proposal is consistent with Lanza and Zanella (1993), Tarling et al. (1999), Vizán and Van Zele (2001), Mena et al. (2006) who have suggested that the remarkable dispersion of Jurassic-early Cretaceous paleomagnetic data may be due to larger magnitudes of the secular variation than at present, or to transitional phases of the geomagnetic field during this time span of high frequency of reversals (as documented by several magnetostratigraphies). It is important to note that in the above-mentioned works the authors analyzed paleomagnetic data from limestones, dolerites and volcanic rocks, which are not affected by inclination flattening.

\subsection{Validation of the results}

Virtual Geomagnetic Poles (VGPs) were calculated from the 30 mean site directions, which are dispersed due to geomagnetic field behavior (see Lanza and Zanella, 1993; Tarling et al., 1999; Vizán and Van Zele, 2001; Mena et al., 2006). To determine the Chon Aike Formation paleomagnetic pole, an iterative method looking for the highest precision parameter Kappa (Fisher, 1953) in the calculation of the average pole was applied: only those VGPs that were inside a cut-off angle of $40^{\circ}$ to the mean pole, were averaged (Wilson et al., 1972). Seven VGPs were excluded because they differ $>40^{\circ}$ (sites with $* *$ in Table 1, Fig. 9) from the mean pole. Its geographic coordinates and 


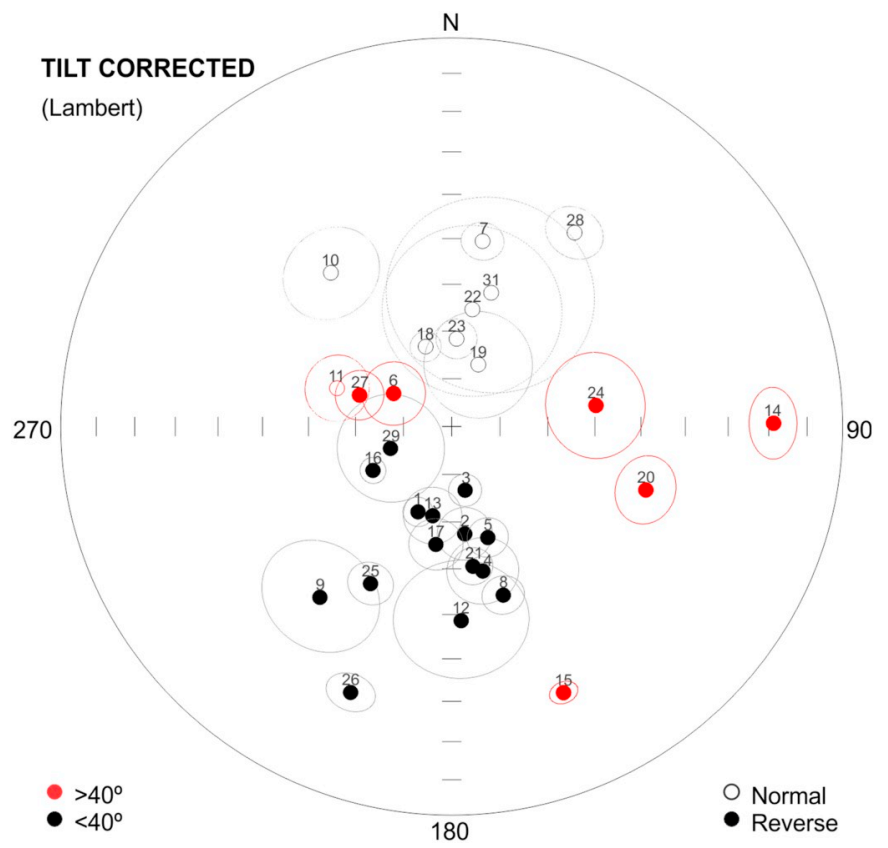

Fig. 7. Stereographic projection of the mean ChRM directions of the 30 sites. In red the discarded ones outside a $40^{\circ}$ interval with respect to the mean direction (see text). (For interpretation of the references to color in this figure legend, the reader is referred to the web version of this article.)

statistical parameters are: Lat. $=84.3^{\circ} \mathrm{S}$, Long. $=191.3^{\circ} \mathrm{E}, \mathrm{A}_{95}=8.6^{\circ}$, $\mathrm{K}=13.3, \mathrm{~N}=23$.

In order to assess the reliability of the calculated pole a reversal test was carried out (see Table 1), on the associated directions (McFadden and McElhinny, 1990) using the implementation in the IAPD software of Torsvik et al. (2014). Applying the test to the 23 sites that are used in the calculation of the pole, yields a "Class C" results, with an observed angle of $2.21^{\circ}$, within the critical angle of $14.23^{\circ}$ (McFadden and McElhinny, 1990).

As pointed out by Deenen et al. (2011), among others, secular variation produces a circular distribution of poles about a mean pole, rather than a circular distribution of directions about a mean direction. It is therefore, perhaps, more appropriate to carry out the reversal test on the distribution of poles. For this purpose, the paleomagnetism.org platform (Koymans et al., 2016) was visited and using the tap "Common
Mean True Directions" the reversal test was carried out, which uses the Monte Carlo simulation. It yields a "Class B" result, with an observed angle of $6.21^{\circ}$ within a critical angle of $7.40^{\circ}$.

These positive tests imply that demagnetization was successful in defining the primary magnetization.

\section{Discussion}

This new paleomagnetic pole supersedes the one obtained by Vizán (1998), which was derived from the average of previous data by Valencio and Vilas (1970) and Vilas (1974), for the Chon Aike Magmatic Province. The original data was determined without using orthogonal diagrams and principal component analyses. As previously explained, this previous pole was calculated for rocks of the Chon Aike Magmatic Province, which by definition has a much wider distribution in Patagonia with a wider range of ages (158.4 Ma by Féraud et al., 1999; to 178.4 Ma by Pankhurst et al., 2000) in comparison to the new pole presented here for the Chon Aike Formation (151.5 to 158.4 Ma, see Fig. 1).

In the Andean Cordillera some $70 \mathrm{~km}$ west of the sampled ignimbritic plateau of the Chon Aike Formation the El Quemado Complex, of comparable age and similar lithologies outcrops (Fig. 1) and has been paleomagnetically studied previously (Iglesia Llanos et al., 2003). Both, the Chon Aike Formation and El Quemado Complex paleomagnetic poles are indistinguishable at the 95\% confidence level (Fig. 10). The El Quemado Complex is not believed to have suffered resetting of its geochronological age nor has it been affected by local tectonic rotations detectable by paleomagnetism.

Besides this new Chon Aike Formation and the existing El Quemado Complex paleomagnetic poles, there are no recent paleomagnetic data for cratonic South America around the age of 155 Ma. To check if the Deseado Massif formed an integral part of South America for Late Jurassic times, these paleomagnetic poles were compared with younger and older reliable poles from NE Brazil (Table 2, Fig. 10). The paleomagnetic poles from Brazil belong to different dike swarms that have been well dated using the K-Ar method. This method, while not as robust as more modern methods, was applied to only highly selected fresh rocks following detailed petrographic analysis of the samples. Those samples containing glass, clay minerals associated with alteration or secondary minerals were carefully avoided (Mizusaki et al., 2002). These dates are therefore considered reliable. Age dating, geochemical and paleomagnetic results allowed division into two clear groups of dikes, one at $186 \mathrm{Ma}$ and one at $135 \mathrm{Ma}$ (Ernesto et al., 2003).

The poles from Patagonia lie between the Brazilian poles, and their
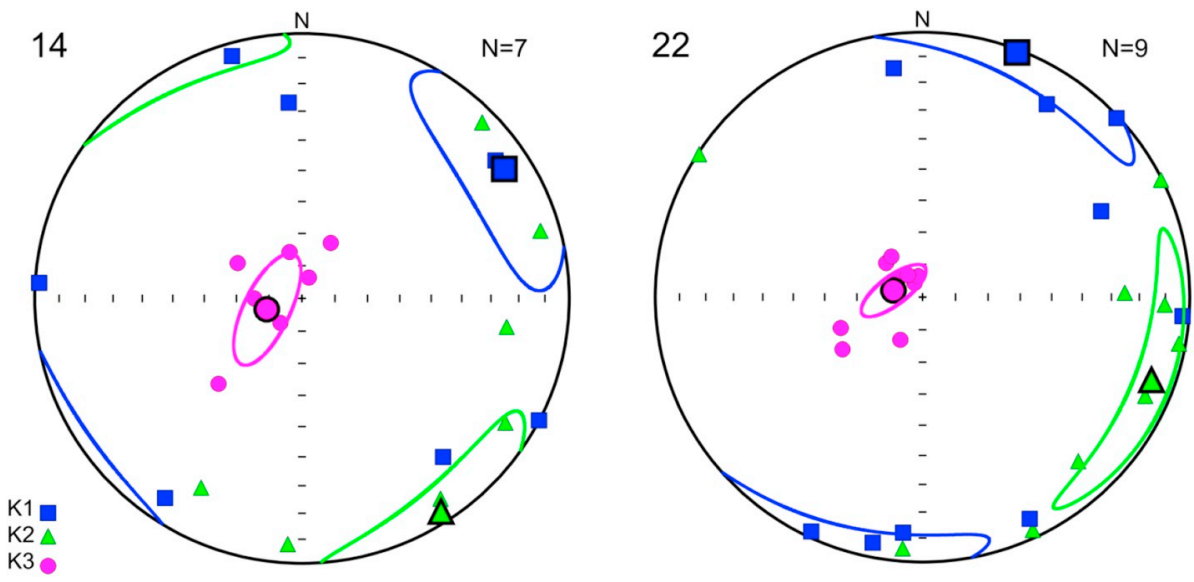

Fig. 8. Stereographic projection of the AMS results (K1 > K2 > K3) of two different ignimbrites (sites 14 \& 22) showing similar magnetic fabrics but corresponding to very different ChRM directions (see Table 1). This essentially flat flying fabric is representative of ignimbritic flow but also showing a slight inclination of the fabric contrary to the direction of flow (similar to sedimentary fabrics). 


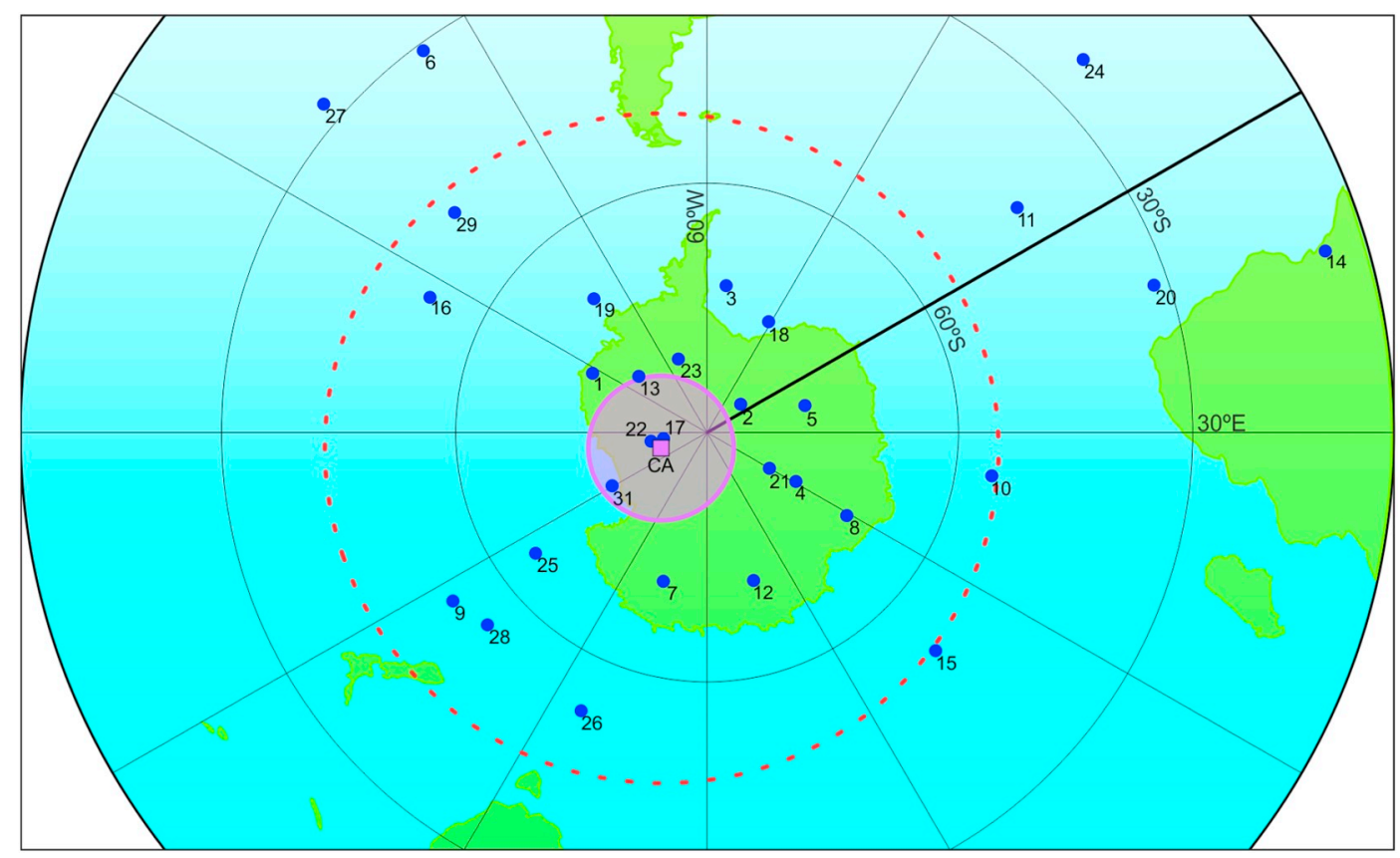

Fig. 9. Virtual geomagnetic poles (blue dots) calculated with the mean site directions. The paleomagnetic pole (with its $95 \%$ confidence cone, $A_{95}=8.6^{\circ}$ ) is shown in purple. The circumference of the broken red line is the cut-off angle of $40^{\circ}$ used in an iterative method to obtain the average pole (see text). (For interpretation of the references to color in this figure legend, the reader is referred to the web version of this article.)

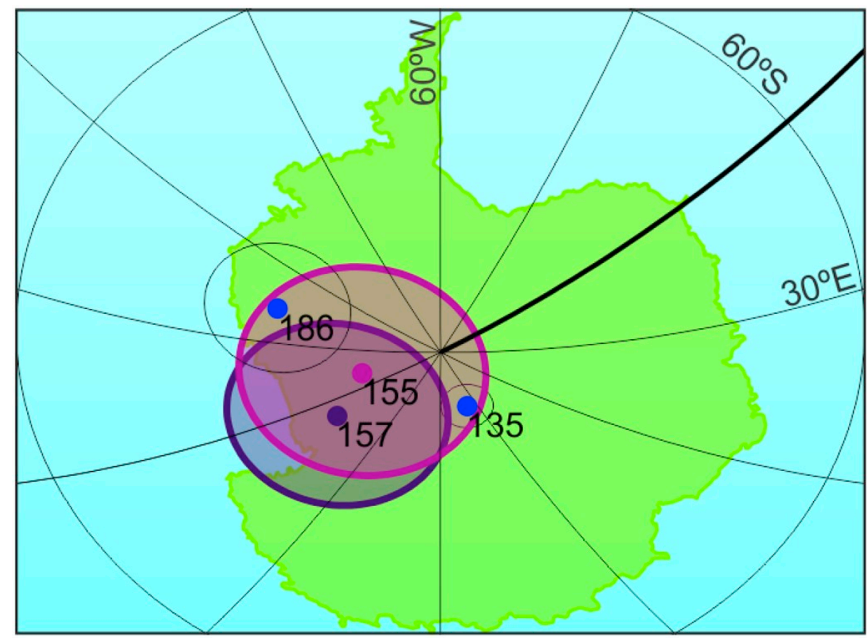

Fig. 10. Chon Aike Formation (purple) and El Quemado Complex paleomagnetic poles (deep purple) between the poles obtained from the NE Brazil dikes (Ernesto et al., 1999) (see Table 2). (For interpretation of the references to color in this figure legend, the reader is referred to the web version of this article.)

confidence intervals overlap each other (Fig. 10). This indicates that southern Patagonia was indeed an integral part of the South American continent during the Late Jurassic. Based on previous analyses, vertical axis tectonic rotations in the Deseado Massif proposed by Somoza et al. (2008) must be older than $155 \mathrm{Ma}$. On the other hand, the Chon Aike Formation and El Quemado Complex paleomagnetic poles can be used to construct an APW path for South America during the Mesozoic (see Table 2).

An APW path for South America was constructed (Fig. 11) for the period from 203 to $102 \mathrm{Ma}$ using only paleomagnetic poles obtained from igneous rocks to avoid any suspicion of inclination shallowing but excluding the Lepá-Osta Arena pole (Vizán, 1998) that may have been affected by tectonic issues (Zaffarana and Somoza, 2012). These paleomagnetic poles (Table 2) are presented in South American geographic coordinates together with the new Chon Aike Formation pole. There are five well-grouped poles from 201 to $198 \mathrm{Ma}$ (14-17 in Table 2), and two with equivalent ages (Anari-Tapirapua Formation and Bolivar Dykes, 12 and 19 in Table 2) that show slightly different geographic locations, perhaps due to unresolved tectonic problems. There is another tight group of paleomagnetic poles from 145 to $129 \mathrm{Ma}$ (3-9 in Table 2); and Marifil Fm., Chon Aike Fm. and El Quemado Complex paleomagnetic poles forming the group in the middle (10-12 in Table 2). The Marifil Formation pole would represent a record of the poleward drift of South America between these two main paleomagnetic pole groups.

Somoza and Zaffarana (2008) proposed a polar standstill between ca. 125 to at least $100 \mathrm{Ma}$. Despite the need for more reliable and welldated paleomagnetic poles of stable South America for the Mesozoic period, it is clear that between $\sim 155 \mathrm{Ma}$ and $102 \mathrm{Ma}$ there is very little change in the paleomagnetic pole position.

Indeed, all poles for the past 200 m.y. should closely resemble each other and internal displacement between different blocks within South America may be difficult to discern because South America has essentially stayed at the same latitude throughout that period (Torsvik et al., 2009).

Kent and Irving (2010) and Kent et al. (2015) motivated by Steinberger and Torsvik (2008) and Torsvik et al. (2012) have suggested a very large and rapid phase of TPW between 200 and 140 Ma. A TPW event, by definition, should be detectable in all tectonic plates and would involve a displacement about an Euler pole located close to the equatorial plane (Marcano et al., 1999). Recently, Fu and Kent (2018) performed an analysis on core samples of the Pacific ocean basin and suggested that large amplitude TPW occurred as recently as the Late Jurassic, however further paleomagnetic experiments on both 
Table 2

Cretaceous and Jurassic poles for South America (in South American coordinates).

\begin{tabular}{|c|c|c|c|c|c|c|}
\hline Age (Ma) & Code & Rock unit & Lat $\left({ }^{\circ} \mathrm{S}\right)$ & Lon $\left({ }^{\circ} \mathrm{E}\right)$ & A95 (deg) & References \\
\hline 102 & 1 & Santo Agostinho Lavas & -87.6 & 315 & 4.5 & Schult and Guerreiro (1980) \\
\hline 121 & 2 & Florianopolis Dykes & -89.1 & 3.3 & 2.6 & Raposo et al. (1998) \\
\hline 129 & 3 & Paraguay alkaline province & -85.4 & 62.3 & 3.1 & Ernesto et al. (1999) \\
\hline 130 & 4 & Sierras Pampeanas in Córdoba & -86 & 75.9 & 3.3 & Geuna and Vizán (1998) \\
\hline 132 & 5 & Posadas Formation & -87.6 & 150.8 & 3.5 & Mena et al. (2006) \\
\hline 132 & 6 & Central Paraná LIP & -84.1 & 64.4 & 2.3 & Ernesto et al. (1999) \\
\hline 132 & 7 & Northern Paraná LIP & -83.3 & 71.4 & 2.4 & Ernesto et al. (1999) \\
\hline 133 & 8 & Southern Paraná LIP & -84 & 106.2 & 1.5 & Ernesto et al. (1999) \\
\hline $125-145$ & 9 & NE Brazil magmatism-1 & -85.2 & 97.6 & 1.8 & Ernesto et al. (2003) \\
\hline 155 & 10 & Chon Aike Formation & -84.3 & 191.3 & 8.6 & This paper \\
\hline 157 & 11 & El Quemado Complex & -81 & 172 & 7.6 & Iglesia Llanos et al. (2003) \\
\hline 183 & 12 & Marifil Formation & -83 & 138 & 11 & Iglesia Llanos et al. (2003) \\
\hline 197 & 13 & Anari-Tapirapua Formation & -65.5 & 250.3 & 3.6 & Montes-Lauar et al. (1995) \\
\hline $175-198$ & 14 & NE Brazil magmatism-2 & -78.1 & 223.9 & 5.2 & Ernesto et al. (2003) \\
\hline 198 & 15 & French Guyana dikes & -81.2 & 235.1 & 4 & Nomade et al. (2000) \\
\hline 199 & 16 & Roraima dikes & -80.1 & 235.1 & 6.6 & Marzoli et al. (1999) \\
\hline 200 & 17 & Cacipore dikes & -79.8 & 208.6 & 5.2 & Ernesto et al. (2003) \\
\hline 201 & 18 & South America CAMP mean & -75.9 & 237.6 & 6.8 & Kent and Irving (2010) \\
\hline 203 & 19 & Bolivar Dykes & -66.9 & 245.6 & 4.9 & MacDonald and Opdyke (1974) \\
\hline
\end{tabular}

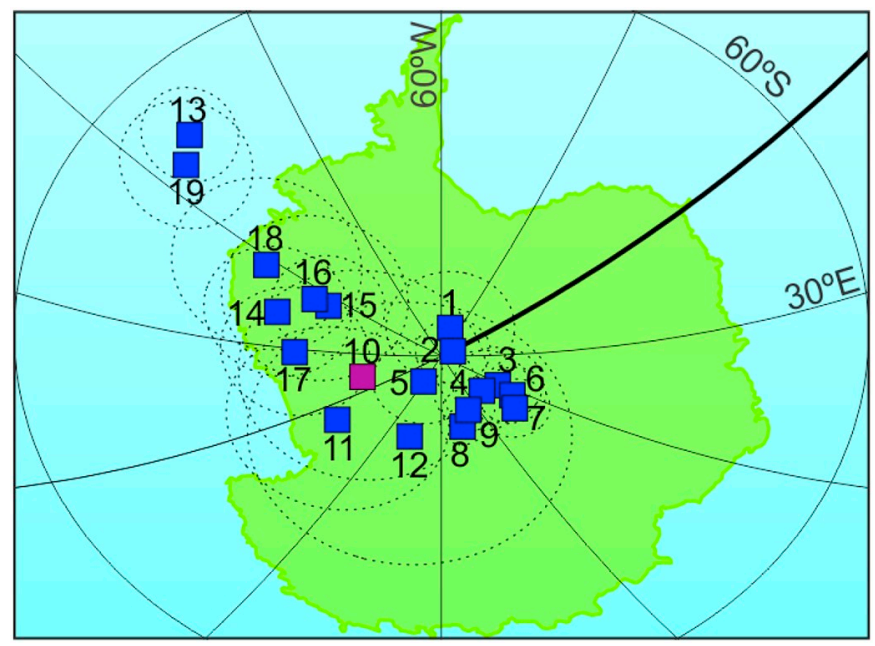

Fig. 11. Paleomagnetic poles of igneous rock from South America between 203 and $102 \mathrm{Ma}$ (see Table 2). The new Chon Aike pole of this paper is marked in purple. (For interpretation of the references to color in this figure legend, the reader is referred to the web version of this article.)

continental and oceanic crust material during the Late Jurassic to Early Cretaceous are necessary to test this motion. To evaluate if South American paleomagnetic data support this suggestion we compare an APW path of this continent between ca. $200 \mathrm{Ma}$ and ca. $100 \mathrm{Ma}$ with global APW paths for this time span of Torsvik et al. (2012) and Kent and Irving (2010), in South African geographic coordinates, using the Euler rotation parameters proposed by the respective authors (Fig. 12a and b). The South America APW path was constructed using a running mean with 20 m.y. windows (Table 3). The South American mean poles compare closely with the global mean path of Torsvik et al. (2012) (Fig. 12a). There are some differences between both APW paths but, essentially, the South America path shows a clear counter-clockwise loop as in the global APW path of Torsvik et al. (2012). In contrast, the South American mean poles contrast sharply with the global APW path of Kent and Irving (2010) differing by some $25^{\circ}$ between 160 and $140 \mathrm{Ma}$ (Fig. 12b). The track between 180 and $140 \mathrm{Ma}$ of the running mean APW path for South America does not support the huge shift suggested by Kent and Irving (2010), Kent et al. (2015) and Fu and Kent (2018).
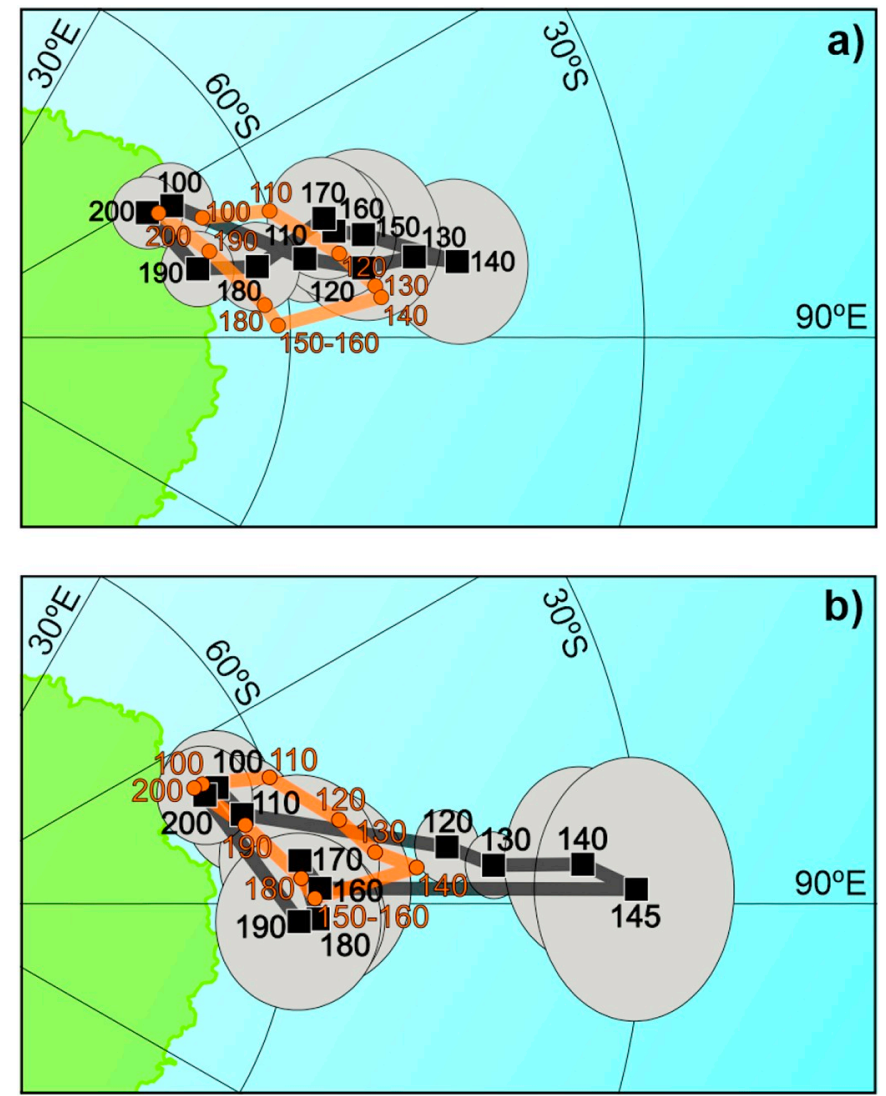

Fig. 12. Running Mean APW paths of South America (see Table 3) rotated to South Africa frame (orange) and compared with previous Global Running Mean APW paths (gray) from: a) Torsvik et al. (2012); b) Kent and Irving (2010).

\section{Conclusions}

A reliable paleomagnetic pole which indicates that southern Patagonia was an integral part of South America during the Late Jurassic is presented.

Vertical axis tectonic rotations in the Deseado Massif proposed by Somoza et al. (2008) during Gondwana break-up must be older than $155 \mathrm{Ma}$.

Currently, reliable South American paleomagnetic poles do not 
Table 3

Running Mean APW path for South America rotated to South Africa Frame in South African coordinates.

\begin{tabular}{|c|c|c|c|c|c|c|}
\hline \multicolumn{3}{|l|}{ Age (Ma) } & \multicolumn{2}{|c|}{$\begin{array}{l}\text { South Africa Frame (Kent } \\
\text { and Irving, 2010) }\end{array}$} & \multicolumn{2}{|c|}{$\begin{array}{l}\text { South Africa Frame (Torsvik } \\
\text { et al., 2012) }\end{array}$} \\
\hline $\pm 10 \mathrm{Ma}$ & $\mathrm{N}$ & A95 & Plat & Plon & Plat & Plon \\
\hline 100 & 1 & - & -65.20 & 67.65 & -65.20 & 67.65 \\
\hline 110 & & - & -59.93 & 70.55 & -59.93 & 70.55 \\
\hline 120 & 3 & 3.6 & -55.38 & 78.89 & -55.38 & 78.89 \\
\hline 130 & 8 & 2 & -52.85 & 83.66 & -52.85 & 83.66 \\
\hline 140 & 6 & 2.2 & -49.52 & 85.9 & -52.44 & 85.14 \\
\hline 150 & 2 & 8.8 & -58.02 & 89.25 & -61.00 & 88.17 \\
\hline 160 & 2 & 8.8 & -58.02 & 89.25 & -61.00 & 88.17 \\
\hline 180 & 2 & 29.5 & -59.05 & 86.26 & -61.96 & 84.80 \\
\hline 190 & 6 & 7.5 & -62.91 & 76.74 & -65.54 & 73.88 \\
\hline 200 & 6 & 6.5 & -65.92 & 67.71 & -68.22 & 63.32 \\
\hline
\end{tabular}

show a significant amount of APW in Jurassic - Cretaceous times and therefore do not support a TPW event at this time.

\section{Acknowledgments}

We dedicate this paper in the loving memory of our friend and teacher Rubén Somoza, sit tibi terra levis. We thank CONICET (Consejo Nacional de Investigaciones Científicas de Argentina) and UBA (Universidad de Buenos Aires) for the financial support (PIP 11220120100200CO and UBACyT 20020150100069BA). Corrections and helpful comments by the editor and reviewers were truly appreciated. We also thank Trond Torsvik for his suggestions for the improvement of the manuscript, and, special thanks to Conall Mac Niocaill for helping us to achieve a much-improved manuscript with his suggestions and his help in English.

\section{Appendix A. Supplementary data}

Supplementary data to this article can be found online at https:// doi.org/10.1016/j.tecto.2018.10.028.

\section{References}

Deenen, M.H.L., Langereis, C.G., van Hisbergen, D.J.J., Biggin, A.J., 2011. Geomagnetic secular variation and the statistics of palaeomagnetic directions. Geophys. J. Int. 186, 509-520. https://doi.org/10.1111/j.1365-246X.2011.05050.x.

Echeveste, H., Fernández, R., Llambías, E., Tessone, M., Schalamuk, I., Bellieni, G., Piccirillo, E., De Min, A., 1999. Ignimbritas tardías de alto grado en la Formación Chon Aike (Jurásico) Macizo del Deseado, Santa Cruz. XIV Congreso Geológico Argentino, Actas 2, 182-185, Salta, Argentina.

Ernesto, M., Raposo, M.I.B., Marques, L.S., Renne, P.R., Diogo, L.A., de Min, A., 1999. Paleomagnetism, geochemistry, and ${ }^{40} \mathrm{Ar} /{ }^{39} \mathrm{Ar}$ dating of the North-eastern Paraná Magmatic Province: tectonic implications. J. Geodyn. 28, 321-340. https://doi.org/ 10.1016/S0264-3707(99)00013-7.

Ernesto, M., Bellieni, G., Piccirillo, E.M., Marques, L.S., de Min, A., Pacca, I.G., Martins, G., Macedo, J.W.P., 2003. Paleomagnetic and geochemical constraints on the timing and duration of the CAMP activity in northeastern Brazil. In: Hames (Ed.), The Central Atlantic Magmatic Province: Insights From Fragments of Pangea. AGU Geophysical Monograph 136. pp. 129-149. https://doi.org/10.1029/136GM07.

Féraud, G., Alric, V., Fornari, M., Bertrand, C., Haller, M., 1999. ${ }^{40} \mathrm{Ar}^{39} \mathrm{Ar}$ dating of the Jurassic volcanic province of Patagonia: migrating magmatism related to Gondwana break-up and subduction. Earth Planet. Sci. Lett. 172, 83-96. https://doi.org/10. 1016/S0012-821X(99)00190-9.

Fisher, R.A., 1953. Dispersion on a sphere. Proceedings Royal Society A217, 295-305. https://doi.org/10.1098/rspa.1953.0064.

Fu, R.R., Kent, D.V., 2018. Anomalous Late Jurassic motion of the Pacific Plate with implications for true polar wander. Earth Planet. Sci. Lett. 490, 20-30. https://doi. org/10.1016/j.epsl.2018.02.034.

Geuna, S.E., Vizán, H., 1998. New Early Cretaceous palaeomagnetic pole from Córdoba Province (Argentina): revision of previous studies and implications for the South American database. Geophys. J. Int. 135, 1085-1100. https://doi.org/10.1046/j. 1365-246X.1998.00688.x.

Goldreich, P., Toomre, A., 1969. Some remarks on polar wandering. J. Geophys. Res. 74, 2555-2567. https://doi.org/10.1029/JB074i010p02555.

Gordon, R.G., Livermore, R.A., 1987. Apparent polar wander of the mean-lithosphere reference frame. Geophys. J. R. Astron. Soc. 91, 1049-1057. https://doi.org/10. 1111/j.1365-246X.1987.tb01679.x. von Gosen, W., Loske, W., 2004. Tectonic history of Calcatapul formation, Chubut Province, Argentina, and the "Gastre fault system". J. S. Am. Earth Sci. 18, 73-88. https://doi.org/10.1016/j.jsames.2004.08.007.

Iglesia Llanos, M.P., Lanza, R., Riccardi, A.C., Geuna, S.E., Laurenzi, M.A., Ruffini, R., 2003. Palaeomagnetic study of the El Quemado complex and Marifil formation, Patagonian Jurassic igneous province, Argentina. Geophys. J. Int. 154, 599-617. https://doi.org/10.1046/j.1365-246X.2003.01923.x.

Kay, S., Ramos, V., Mpodozis, C., Sruoga, P., 1989. Late Paleozoic to Jurassic silicic magmatism at the Gondwana margin: Analogy to the Middle Proterozoic in North America? Geology 17, 324-328. https://doi.org/10.1130/0091-7613(1989) $017<0324:$ LPTJSM > 2.3.CO;2.

Kent, D.V., Irving, E., 2010. Influence of inclination error in sedimentary rocks on the Triassic and Jurassic apparent polar wander path for North America and implications for Cordilleran tectonics. J. Geophys. Res. 115, B10103. https://doi.org/10.1029/ 2009JB007205.

Kent, D.V., Kjarsgaard, B.A., Gee, J.S., Muttoni, G., Heaman, L.M., 2015. Tracking the Late Jurassic apparent (or true) polar shift in U-Pb-dated kimberlites from cratonic North America (Superior Province of Canada). Geochem. Geophys. Geosyst. 16, 983-994. https://doi.org/10.1002/2015GC005734.

Kirschvink, J.L., 1980. The least-squares line and plane and the analysis of palaeomagnetic data. Geophys. J. R. Astron. Soc. 62, 699-718. https://doi.org/10.1111/j.1365246X.1980.tb02601.x.

Koymans, M.R., Langereis, C.G., Pastor-Galan, D., van Hinsbergen, D.J.J., 2016. Paleomagnetism.org: an online multi-platform open source environment for paleomagnetic data analysis. Comput. Geosci. 93, 127-137. https://doi.org/10.1016/j. cageo.2016.05.007.

Lanza, R., Zanella, E., 1993. Palaeomagnetism of the Ferrar dolerite in the northern Prince Albert Mountains (Victoria Land, Antarctica). Geophys. J. Int. 114, 501-511.

Magnetic Prospecting. In: Lanza, R., Meloni, A. (Eds.), The Earth's Magnetism: An Introduction for Geologists. Springer Berlin Heidelberg, Berlin, Heidelberg, pp. 99-126. https://doi.org/10.1007/978-3-540-27980-8_3.

MacDonald, W.D., Opdyke, N.D., 1974. Triassic paleomagnetism of northern South America. Am. Assoc. Pet. Geol. Bull. 58, 208-215.

Marcano, M.C., van der Voo, R., Mac Niocaill, C., 1999. True polarwander during the Permo-Triassic. Geodynamics 28, 75-95. https://doi.org/10.1016/S0264-3707(98) 00026-X.

Marzoli, A., Renne, P.R., Piccirillo, E.M., Ernesto, M., Gellieni, G., De Min, A., 1999. Extensive 200-million-year-old continental flood basalts of the Central Atlantic Magmatic Province. Science 284, 616-618. https://doi.org/10.1126/science.284. 5414.616.

McFadden, P.L., McElhinny, M.W., 1990. Classification of the reversal test in palaeomagnetism. Geophys. J. Int. 103, 725-729. https://doi.org/10.1111/j.1365-246X. 1990.tb05683.x.

Mena, M., Orgeira, M.J., Lagorio, S.L., 2006. Paleomagnetism, rock-magnetism and geochemical aspects of early Cretaceous basalts of the Paraná Magmatic Province, Misiones, Argentina. Earth Planets Space 58, 1283-1293. https://doi.org/10.1186/ BF03352623.

Mizusaki, A.M.P., Thomaz-Filho, A., Milani, E.J., de Cesero, P., 2002. Mesozoic and Cenozoic igneous activity and its tectonic control in northeastern Brazil. J. S. Am. Earth Sci. 15, 183-198. https://doi.org/10.1016/S0895-9811(02)00014-7.

Montes-Lauar, C.R., Pacca, I.G., Melfi, A.J., Kawashita, K., 1995. Late Cretaceous alkaline complexes, southeastern Brazil: paleomagnetism and geochronology. Earth Planet. Sci. Lett. 134, 425-440. https://doi.org/10.1016/0012-821X(95)00135-Y.

Moreira, P., Echeveste, H., Fernández, R., Hartmann, L., Santos, J., 2006. Ajuste geocronologico de la Formacion Chon Aike y mineralizaciones epitermales asociadas mediante determinaciones isotopicas U-Pb SHRIMP en circones. In: XI Congreso Geologico Chileno, Actas. 2. pp. 311-314.

Nomade, S., Theveniaut, H., Chen, Y., Pouclet, A., Rigollet, C., 2000. Paleomagnetic study of French Guyana Early Jurassic dolerites: hypothesis of a multistage magmatic event. Earth Planet. Sci. Lett. 184, 155-168. https://doi.org/10.1016/S0012-821X (00)00305-8.

Pankhurst, R., Riley, T., Fanning, C., Kelley, S., 2000. Episodic Silicic Volcanism in Patagonia and the Antartic Peninsula: chronology of magmatism associated with the Break-up of Gondwana. J. Petrol. 41 (5), 605-625. https://doi.org/10.1093/ petrology/41.5.605.

Panza, J.L., Haller, M., 2002. El volcanismo jurásico. Geología y Recursos Naturales de Santa Cruz. In: Haller, M. (Ed.), XV Congreso Geológico Argentino, Relatorio, Capítulo I-7, pp. 89-101.

Raposo, M.I.B., Ernesto, M., Renne, P.R., 1998. Paleomagnetism and ${ }^{40} \mathrm{Ar} /{ }^{39} \mathrm{Ar}$ dating of the early Cretaceous Florianópolis dike swarm (Santa Catarina Island), Southern Brazil. Phys. Earth Planet. Inter. 108, 275-290. https://doi.org/10.1016/S0031 9201(98)00102-2.

Schult, A., Guerreiro, S.D.C., 1980. Paleomagnetism of Upper Cretaceous volcanic rocks from Cabo de Sto. Agostinho, Brazil. Earth Planet. Sci. Lett. 50, 311-315. https://doi. org /10.1016/0012-821X(73)90103-9.

Somoza, R., Zaffarana, C.B., 2008. Mid-Cretaceous polar standstill of South America, motion of the Atlantic hotspots and birth of the Andean cordillera. Earth Planet. Sci. Lett. 271, 267-277. https://doi.org/10.1016/j.epsl.2008.04.004.

Somoza, R., Vizán, H., Taylor, G.K., 2008. Tectonic rotations in the Deseado Massif, southern Patagonia, during the breakup of Western Gondwana. Tectonophysics 460, 178-185. https://doi.org/10.1016/j.tecto.2008.08.004.

Steinberger, B., Torsvik, T.H., 2008. Absolute plate motions and true polar wander in the absence of hotspots tracks. Nature 452, 620-623. https://doi.org/10.1038/ nature 06824.

Tarling, D.H., Iorio, M., D'Argenio, B., 1999. Geomagnetic long-term secular variation in Italian lower Cretaceous shallow-water carbonates. Geophys. J. Int. 137, 713-722. https://doi.org/10.1046/j.1365-246x.1999.00820.x.

Torsvik, T.H., Rousse, S., Labails, C., Smethurst, M.A., 2009. A new scheme for the opening of the South Atlantic Ocean and the dissection of an Aptian salt basin. Geophys. J. Int. 177, 1315-1333. https://doi.org/10.1111/j.1365-246X.2009. 
04137.x

Torsvik, T.H., Van der Voo, R., Predeen, U., Mac Niocaill, C., Steinberger, B., Doubrovine, P.V., van Hinsbergen, D.J.J., Domeier, M., Gaina, C., Tohver, E., Meert, J.G., McCausland, P.J.A., Cocks, L.R.M., 2012. Phanerozoic polar wander, paleogeography and dynamics. Earth Sci. Rev. 114, 325-368. https://doi.org/10.1016/j.earscirev. 2012.06.007.

Torsvik, T.H., Doubrovine, P.V., Domeier, M., 2014. Super-IAPD, Ivar Giæver Geomagnetic Laboratory, Research Council of Norway (NFR), Centre for Earth Evolution and Dynamics (CEED) and University of Oslo (UiO). http://www.iggl.no/ resources.html\#software.

Valencio, D.A., Vilas, J.F.A., 1970. Paleomagnetism of some Middle Jurassic lavas from South-east Argentina. Nature 225, 262-264. https://doi.org/10.1038/225262a0.

Vilas, J.F.A., 1974. Paleomagnetism of some igneous rocks of the Middle Jurassic ChonAike Formation from Estancia La Reconquista, Province of Santa Cruz, Argentina. Geophys. J. R. Astron. Soc. 39, 511-522. https://doi.org/10.1111/j.1365-246X. 1974.tb05469.x.

Vizán, H., 1998. Paleomagnetism of the Lower Jurassic Lepa and Osta Arena formations,
Argentine Patagonia. J. S. Am. Earth Sci. 11, 333-350. https://doi.org/10.1016/ S0895-9811(98)00018-2.

Vizán, H., Van Zele, M.A., 2001. Analysis of the early Jurassic geomagnetic data recorded at the Bregia Gorge (Ticino, Switzerland). Phys. Earth Planet. Inter. 125, 19-29. https://doi.org/10.1016/S0031-9201(01)00207-2.

Wilson, R.L., Dagley, P., McCormack, A.G., 1972. Palaeomagnetic evidence about the source of the geomagnetic field. Geophys. J. R. Astron. Soc. 28, 213-224. https://doi. org/10.1111/j.1365-246X.1972.tb06124.x.

Zaffarana, C.B., López de Luchi, M.G., Somoza, R., Mercader, R., Giacosa, R., Martino, R.D., 2010. Anisotropy of magnetic susceptibility study in two classical localities of the Gastre Fault System, central Patagonia. J. S. Am. Earth Sci. 30, 151-166. https:// doi.org/10.1016/j.jsames.2010.10.003.

Zaffarana, C.B., Somoza, R., 2012. Palaeomagnetism and 40Ar/39Ar dating from Lower Jurassic rocks in Gastre, central Patagonia: further data to explore tectonomagmatic events associated with the break-up of Gondwana. J. Geol. Soc. 169, 371-379. https://doi.org/10.1144/0016-76492011-089. 